\title{
Human Capital in the Strategic Development of the Transport System of Russia. The Case of JSC Russian Railways
}

\author{
Nina M. Baranova ${ }^{1}$, and Daria S. Loginova ${ }^{1,2}$ \\ ${ }^{1}$ Faculty of Economics, Department of Economic and Mathematical modeling, Peoples' Friendship \\ University of Russia (RUDN University), 6, Miklukho-Maklaya Str, 117198, Moscow, Russia \\ ${ }^{2}$ Laboratory of simulation modeling of the interaction of economic objects, CEMI RAS (Central \\ Economics and Mathematics Institute of Russian Academy of Science), 47, Nakhimovsky prospect, \\ 117418, Moscow, Russia
}

\begin{abstract}
The transport system plays a significant part in the modern life. Tasks that arise in various sectors of the national economy can be solved quickly and efficiently thanks to well-functioning logistics. One of the largest transport companies in the world is JSC Russian Railways (JSC RZD), Russia. According to the results of 2019, the company ranked first in the world in terms of freight turnover (2.6 trillion tonne-kilometres), third in terms of cargo carriage volume (1.3 billion tons) and the miles open (85.6 thousand $\mathrm{km})$, fourth in terms of passenger turnover $(134.5$ billion passenger-kilometres). It is obvious that such high indicators of the company were achieved thanks to a modern scientific and technical base, design and construction capacities, international cooperation, and, most importantly, highly qualified specialists at all levels. Positive human capital (HC) significantly affects the efficient use of all types of resources of the company, determines the competitiveness and the company value, its leadership in sustainable development. Therefore, the study of the human factor in the development of the transport system in Russia is relevant. The study was carried out using the annual reports of JSC Russian Railways from 2002 to 2019. The econometric (linear and exponential) models were built on the basis of statistical data. The linear model has been proven to provide more accurate predictions.
\end{abstract}

\section{Introduction}

Russia ranked first in traffic safety, second in cargo carriage volume, and fifth in passenger turnover based on 2020 data provided by the International Energy Agency [1]. JSC Russian Railways has set strategic goals until 2030 [2] in the following areas: transport and logistics, passenger and rail transportation, infrastructure, foreign activities, social policy. It will be possible to solve the assigned tasks and enter the top-5 most attractive large employing companies in Russia by attracting the best talents with competitive wages, the best working conditions, modern employee benefits, etc.

*Corresponding author: baranova_nm@pfur.ru 


\section{Staff development of JSC Russian Railways}

A large group of Russian and foreign scientists are engaged in the development of the HC. Among them are the studies of Baranova N.M. [3-4], Matyushok V.M., Sorokin L.V. [4], Emtseva E.D., Krasova E.V., Mazelis L.S., Kras'ko A.A. [5], Golovanova E.N. [6], Kevin D. Carlson, Kavanagh Michael J. [7], Dementyev M.Yu., Lesnetskaya A.O. [8], Sinitskaya N.Ya. [9], etc. The issues of management and effective use of human resources of the company are given considerable attention in the works of Armstrong M., Taylor S. [10], Arymurthy A.M., Cahyaningsih E., Sensuse D.I., Wibowo W.C. [11], Diaz-Fernandez M., Pasamar-Reyes S., Valle-Cabrera R. [12], Ershova N.A. [13], Nojedeh S. H., Pasban M. [14], Kokorina O.K., Sharokhina S.V., Shevchenko T.A. [15], Titov A.A. [16], etc. Scientists Myachikova K.A. and Selina O.V. [17] were engaged in the study of the HC in JSC Russian Railways, however, this study was done only in a descriptive manner. Therefore, an econometric study of this problem would be of interest.

The staff training strategy and its development has become one of the top-priority strategies adopted by JSC Russian Railways [1-2]. Its goal is to provide the company with qualified talents and effective development of human resources. JSC Russian Railways has its own corporate resources for staff training, retraining and advanced training - road technical schools, training centers, Russian University of Transport (RUT (MIIT)). The Corporate University of JSC Russian Railways, certified by The Global Council of Corporate Universities (GlobalCCU), was created to train and develop the competencies of managers at the strategic and tactical management levels of the company. The University is the center of expertise in the field of staff evaluation, development of educational programs, adoption of distant learning technologies, implementation of programs for the development of the company's employee pool (more than 150 educational programs and 60 e-courses). More than 170 thousand of leader personnel and specialists are retrained and upgraded skills annually, more than 60-65 thousand workers are trained, more than 150 thousand people are upgrading their qualifications. 15 training centers for vocational qualifications from 67 divisions are the basis of the corporate vocational training system. The number of company executives studying under MBA programs at leading Russian business schools is growing; more than 600 executives completed an internship at railway transport enterprises in Germany, France, Finland, Austria, etc. Annually more than 30 thousand students of universities and technical schools of railway transport undergo practical training in the structural divisions of the company.

This work made it possible to improve the qualitative composition of the company's staff [18]: the share of young employees and employees with higher and secondary vocational education increased. The professional potential of the company has increased the share of specialists with a higher professional education in the total number of employees increased to $32.8 \%$ in 2019 compared to 2018 , with a secondary vocational education was $28 \%$, the engineering staffing was $100 \%$.

\section{Methods and approaches}

The proceedings of Russian and foreign scientists [3-17, 20] were studied. The annual reports of JSC Russian Railways and statistical data on the development of the company for 2002-2019 [1-2, 18-19] were studied to research the HC development of JSC Russian Railways, and, therefore, the competitiveness of the company for 2002-2019. The regression and econometric analyzes were used to construct the models using MS Excel and Eviews-10 statistical software package. 


\section{The linear model of human capital development at JSC Russian Railways for 2002-2019}

There is need to build an econometric model based on the data of the Annual Reports and Financial Statements of JSC Russian Railways for 2002-2019 [1-2, 18-19] in order to study and assess the development of human capital of JSC Russian Railways. Exogenous and endogenous variables were selected to construct models for the development of the HC using MS Excel regression analysis [21-24].

The regressand Y(NUMBER) was taken as the staff number of the company (in thousand people), the regressors were taken: $\mathrm{X}_{1}$ (INVESTMENT) as the company's investments in R\&D and innovation projects (in billion rubles); $\mathrm{X}_{2}$ (TRAINING) as the number of people, received professional training and retraining, training, staff development (in thousand people); $\mathrm{X}_{3}$ (WAGE) as the average monthly wages (in rubles); $\mathrm{X}_{4}$ (SAFETY) as the expenditures on labor safety (in million rubles). Eviews application program will be used to carry out calculations and construct a forecast [24].

An analysis of covariance was carried out to determine the correlation between the variables $\mathrm{X}_{1}, \ldots, \mathrm{X}_{4}$ and $\mathrm{Y}(\mathrm{NUMBER})$. The pairwise correlation matrix established a close relationship between $\mathrm{Y}(\mathrm{NUMBER})$ and $\mathrm{X}_{1}, \ldots, \mathrm{X}_{4}$ : $\mathrm{R}_{\mathrm{YX} 1}=-0.91, \mathrm{R}_{\mathrm{YX} 2}=-0.7, \mathrm{R}_{\mathrm{YX} 3}=-0.98$, $\mathrm{R}_{\mathrm{YX} 4}=-0.95$. There is a negative relationship between the variables, which speaks of the Pareto principle "80:20", that is fewer highly educated, creative employees are able to do most of the work using modern production methods. The regressors are also more or less associated with each other. So, multicollinearity is present in the model. That is, an additional study of the model parameters is required.

\begin{tabular}{|c|c|c|c|c|}
\hline Variable & Coefficient & Std. Error & t-Statistic & Prob. \\
\hline INVESTMENT & 0.459494 & 0.125460 & 3.662467 & 0.0029 \\
\hline TRAINING & 0.469925 & 0.166009 & 2.830716 & 0.0142 \\
\hline WAGE & -0.024678 & 0.002824 & -8.737985 & 0.0000 \\
\hline SAFETY & 0.017787 & 0.005889 & 3.020301 & 0.0098 \\
\hline $\mathrm{C}$ & 1271.800 & 37.73430 & 33.70408 & 0.0000 \\
\hline R-squared & 0.987685 & \multirow{7}{*}{\multicolumn{2}{|c|}{$\begin{array}{l}\text { Mean dependent var } \\
\text { S.D. dependent var } \\
\text { Akaike info criterion } \\
\text { Schwarz criterion } \\
\text { Hannan-Quinn criter. } \\
\text { Durbin-W ats on stat }\end{array}$}} & 1010.895 \\
\hline Adiusted R-squared & 0.983896 & & & 209.9130 \\
\hline S.E. of reqression & 26.63864 & & & 9.632736 \\
\hline Sum squared resid & 9225.020 & & & 9.880061 \\
\hline Log likelihood & -81.69462 & & & 9.666838 \\
\hline F-statistic & 260.6525 & & & 2.226500 \\
\hline Prob(F-statistic) & 0.000000 & & & \\
\hline
\end{tabular}

Fig. 1. Coefficients and estimation of the linear model parameters

The data in Figure 1 show the significance of the target linear model $\left(\mathrm{F}_{\text {stat }}=260.65\right.$, Prob=0.0000), coefficient of determination $\mathrm{R}^{2}$ is 0.988 . The significance of the target equation and the estimation of the coefficients make it possible to construct a linear model and analyze the relationship between the studied variables. The linear model appears as follows:

$Y^{\wedge}(N U M B E R)=0,4595 \times X_{1}+0,47 \times X_{2}-0,025 \times X_{3}+0,02 \times X_{4}+1271,8$

The fitted values of $Y^{\wedge}(N U M B E R)$, on average, approximate well the dependence of the actual values of $\mathrm{Y}(\mathrm{NUMBER})$ on $\mathrm{X}_{1}, \ldots, \mathrm{X}_{4}$. The Jacques-Bera Test should be examined to investigate the autocorrelation of the residuals for normality (Fig. 2) ( $\mathrm{n}=18$ regressors). 


\begin{tabular}{|ll|}
\hline \multicolumn{2}{|l|}{ Series: Residuals } \\
Sample 2002 2019 \\
Observations & 18 \\
Mean & $8.86 e-14$ \\
Median & 5.287695 \\
Maximum & 26.64315 \\
Minimum & -58.30047 \\
Std. Dev. & 23.29481 \\
Skewness & -0.957205 \\
Kurtosis & 3.208989 \\
& \\
Jarque-Bera & 2.781479 \\
Probability & 0.948891 \\
\hline
\end{tabular}

Fig. 2. Jarque-Bera Test, the linear model

The Jarque-Bera test (Fig. 2) shows that the residuals of the model (1) have normal distribution (2.78), and the $\mathrm{P}$-value is 0.95 (the probability of accepting the hypothesis $\mathrm{H}_{0}$ is $95 \%$ ).

It is also possible to establish the adequacy of the model (1) by the confidence interval and the graph of the fitted $\mathrm{Y}^{\wedge}(\mathrm{NUMBER})$ (Fig. 3).

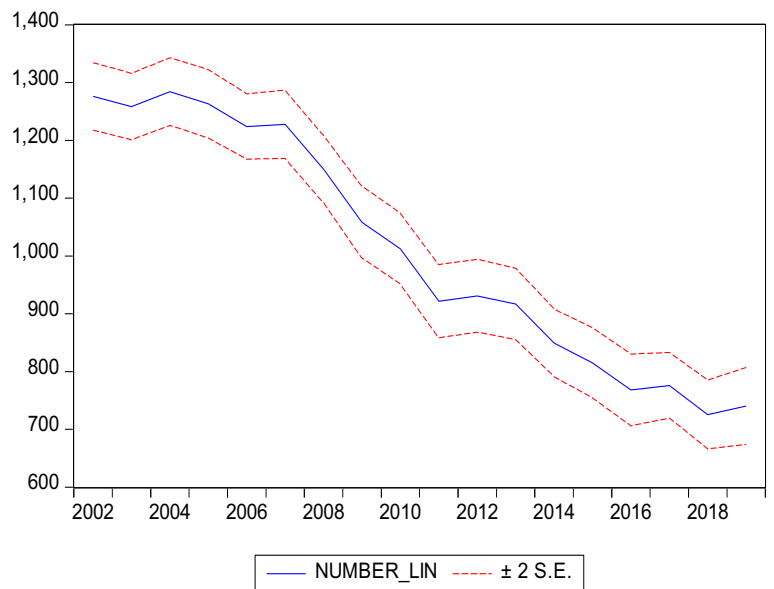

\begin{tabular}{|c|c|}
\hline Forecast: NUMBER LIN & \\
\hline Actual: NUMBER & \\
\hline $\begin{array}{l}\text { Forecast sample: } 2002201 \\
\text { Included observations: } 18\end{array}$ & \\
\hline Root Mean Squared Error & 22.63849 \\
\hline Mean Absolute Error & 18.82322 \\
\hline Mean Abs. Percent Error & 1.846137 \\
\hline Theil Inequality Coefficient & 0.010977 \\
\hline Bias Proportion & 0.000000 \\
\hline Variance Proportion & 0.003098 \\
\hline Covariance Proportion & 0.996902 \\
\hline Theil U2 Coefficient & 0.419586 \\
\hline Symmetric MAPE & 1.840645 \\
\hline
\end{tabular}

Fig. 3. Estimation parameters of the model (1)

Theil inequality coefficient $(0<0.011<1)$ and the mean absolute percent error $(1.85 \%)$ confirm the accuracy of the model (1) (Fig. 3).

White test allows examining the model (1) for the absence of heteroscedasticity. The hypothesis $\mathrm{H}_{0}$ assumes the absence of homoscedasticity of the residuals of the model (1), and $\mathrm{H}_{1}$ is the opposite hypothesis. The result of White test is $O b s^{*} \mathrm{R}^{2}=8.4$, the P-value is 0.87 (Fig. 4). Therefore, the hypothesis $\mathrm{H}_{0}$ about heteroscedasticity of the residuals of the model (1) is rejected, and, consequently, the residuals have constant variance.

\begin{tabular}{llll}
\multicolumn{4}{l}{ Heteroskedasticity Test: White } \\
\hline \hline F-statistic & 0.188116 & Prob. F(14,3) & 0.9882 \\
Obs*R-squared & 8.414703 & Prob. Chi-Square(14) & 0.8666 \\
Scaled explained SS & 4.847793 & Prob. Chi-Square(14) & 0.9878 \\
\hline \hline
\end{tabular}

Fig. 4. White test, the linear model (1)

The Durbin-Watson statistics is $2.23, \mathrm{DW}=2.23$ (Fig. 2). The number of observations $n$ is 18 and the number of regressors is 4 , therefore, $1.6<\mathrm{r}(2.23)<4-1.6$ at the $1 \%$ significance level, put in other words there is no residual autocorrelation in the model (1). Conclusion the model (1) is adequate and can be used for predictive calculations of $\mathrm{Y}^{\wedge}(\mathrm{NUMBER})$. 


\section{The exponential model}

Now let us consider the exponential model [21-24] for forecasting of the development of human capital of JSC Russian Railways. Figure 5 shows the following indicators: $F_{\text {stat }}=108.7$, Prob $=0.0000, R^{2}=0.96$. The data indicate the importance of the exponential model and its usefulness for research and forecasting.

\begin{tabular}{|c|c|c|c|c|}
\hline Variable & Coefficient & Std. Error & t-Statistic & Prob. \\
\hline LOG(INVESTMENT) & 0.258363 & 0.066449 & 3.888108 & 0.0019 \\
\hline LOG(TRAINING) & 0.033715 & 0.062525 & 0.539233 & 0.0988 \\
\hline LOG(WAGE) & -0.407745 & 0.100636 & -4.051670 & 0.0014 \\
\hline LOG(SAFETY) & -0.168871 & 0.083899 & -2.012786 & 0.0653 \\
\hline $\mathrm{C}$ & 10.95651 & 0.334499 & 32.75502 & 0.0000 \\
\hline R-squared & 0.970959 & \multirow{7}{*}{\multicolumn{2}{|c|}{$\begin{array}{l}\text { Mean dependent var } \\
\text { S.D. dependent var } \\
\text { Akaike info criterion } \\
\text { Schwarz criterion } \\
\text { Hannan-Quinn criter. } \\
\text { Durbin-Watson stat }\end{array}$}} & 6.897901 \\
\hline Adjusted R-squared & 0.962023 & & & 0.210124 \\
\hline S.E. of regression & 0.040948 & & & -3.322890 \\
\hline Sum squared resid & 0.021798 & & & -3.075565 \\
\hline Log likelihood & 34.90601 & & & -3.288787 \\
\hline F-statistic & 108.6611 & & & 1.782748 \\
\hline Prob(F-statistic) & 0.000000 & & & \\
\hline
\end{tabular}

Fig. 5. Parameters and estimates of the nonlinear equation

Therefore, the exponential model appears as follows:

$L O G(N U M B E R)=0.258 \times L O G(I N V E S T M E N T)+0.034 \times L O G(T R A I N I N G)-0.408 \times$ $\times L O G(W A G E)-0.169 \times \operatorname{LOG}($ SAFETY $)+10,96$

The fitted LOG_Y^(NUMBER), on average, approximates well the dependence of the actual LOG_Y(NUMBER) on $\mathrm{X}_{1}, \ldots, \mathrm{X}_{4}$. The Jacques-Bera Test should be examined to study the autocorrelation of the residuals for normality (Fig. 6).

\begin{tabular}{|lr|}
\hline \multicolumn{2}{|l|}{ Series: Residuals } \\
Sample 2002 2019 \\
Observations 18 \\
Mean & $1.88 \mathrm{e}-15$ \\
Median & -0.000733 \\
Maximum & 0.076742 \\
Minimum & -0.061181 \\
Std. Dev. & 0.035808 \\
Skewness & 0.097268 \\
Kurtosis & 2.711577 \\
& \\
Jarque-Bera & 0.090774 \\
Probability & 0.955628 \\
\hline
\end{tabular}

Fig. 6. Jarque-Bera Test, the nonlinear model (2)

The Jarque-Bera test (Fig. 6) shows that the residuals of the model (2) have normal distribution (0.091), and the P-value is 0.96 (the probability of accepting the hypothesis $\mathrm{H}_{0}$ is $96 \%$ ).

It is also possible to establish the adequacy of the model (2) by the confidence interval and the graph of the fitted LOG_Y^(NUMBER) (Fig. 7). 


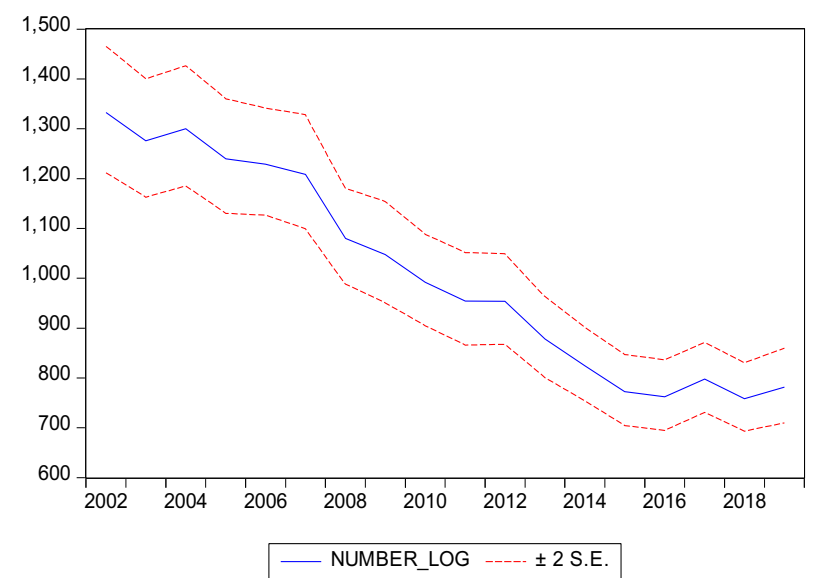

\begin{tabular}{|c|c|}
\hline \\
\hline \multicolumn{2}{|l|}{$\begin{array}{l}\text { Forecast: NUMBER_LOG } \\
\text { Actual: NUMBER }\end{array}$} \\
\hline \multicolumn{2}{|l|}{$\begin{array}{l}\text { Forecast sample: } 20022019 \\
\text { Included observations: } 18\end{array}$} \\
\hline $\begin{array}{l}\text { Included observations: } 18 \\
\text { Root Mean Squared Error }\end{array}$ & 35.70407 \\
\hline Mean Absolute Error & 27.50793 \\
\hline Percent Error & 2.768269 \\
\hline Theil Inequality Coefficient & 0.017316 \\
\hline Bias Proportion & 0.000172 \\
\hline Variance Proportion & 0.000750 \\
\hline Covariance Proportion & 0.999078 \\
\hline Theil U2 Coefficient & 0.681036 \\
\hline Symmetric MAPE & 2.767251 \\
\hline
\end{tabular}

Fig. 7. Estimation parameters of the model (2)

Theil inequality coefficient $(0<0.017<1)$ and the mean absolute percent error $(2.77 \%)$ confirm the accuracy of the model (2) (Fig. 7).

White test allows examining the model (2) for the absence of heteroscedasticity. The hypothesis $\mathrm{H}_{0}$ says there is no homoscedasticity of the residuals of the model (2), and $\mathrm{H}_{1}$ is the opposite hypothesis. The result of White test is $\mathrm{Obs}^{*} \mathrm{R}^{2}=16.4$, the P-value is 0.29 (Fig. 8). Therefore, the hypothesis $\mathrm{H}_{0}$ about heteroscedasticity of the residuals of the model (2) is rejected, and, consequently, the residuals have constant variance.

Heteroskedasticity Test: White

\begin{tabular}{llll}
\hline \hline F-statistic & 2.168658 & Prob. F(14,3) & 0.2861 \\
Obs*R-squared & 16.38135 & Prob. Chi-Square(14) & 0.2906 \\
Scaled explained SS & 7.312368 & Prob. Chi-Square(14) & 0.9220 \\
\hline \hline
\end{tabular}

Fig. 8. White test of the nonlinear model

Figure 5 shows that the Durbin-Watson statistics (DW) is 1.78. The model has 18 observations $(\mathrm{n}=18)$ and 4 regressors, so we get $1.6<\mathrm{r}(1.78)<4-1.6$ at the $1 \%$ significance level, that is there is no residual autocorrelation in the model (2). Therefore, the model (2) is adequate and can also be used for predictive calculations of $\mathrm{LOG}_{-} \mathrm{Y}^{\wedge}(\mathrm{NUMBER})$.

However, the model (1) is more accurate, since $R^{2}(1)=0.988>R^{2}(2)=0.96$ (Figures 1 and 5) and the Theil inequality coefficient of the model (1) is 0.011 , while it is 0.017 in the model (2). Therefore, it is worth using the linear regression model (1) to study the set goal.

\section{Results}

According to the world's scientists, the company's human capital investments offer the greatest promise. This could easily be verified after researching JSC Russian Railways. The projected $Y^{\wedge}(1)$ is calculated for the reporting period for the model (1) according to the reports of JSC Russian Railways for 2002-2019. Further, $\mathrm{X}_{1} ; \ldots$; $\mathrm{X}_{4}$ for 2002-2019 are sequentially substituted into the model (1), and the results of all $Y_{i}^{\wedge}(1), \mathrm{i}=1, \ldots, 18$, are obtained. Comparing the actual $\mathrm{Y}(1)$ and the fitted $\mathrm{Y}^{\wedge}(1)$ for 2002-2019 [1-2, 18-19], one can make sure that the obtained $Y_{i}(1)$ and $Y_{i}^{\wedge}(1), \mathrm{i}=1, \ldots, 18$, practically coincide $\left(\mathrm{Y}_{5}(1)=1243 ; \quad \mathrm{Y}_{5} \wedge(1)=1223 ; \quad \mathrm{Y}_{18}(1)=743,1 ; \quad \mathrm{Y}_{18} \wedge(1)=741,5\right)$. Similarly, a comparative analysis is carried out for $\mathrm{Y} i(2)$ and $Y i^{\wedge}(2)$. The conclusion is the linear (1) and nonlinear (2) models can be used for predictive calculations, but the model (1) is more accurate. 


\section{Conclusions}

JSC Russian Railways is one of the largest employers in Russia (the share of employees amounts to $1 \%$ of employed in the national economy). The staff number, starting from 2002 within the framework of the company optimization project, grew first from 1200 thousand people to 1300 thousand people (in 2003-2004), then gradually began to decline to 743.1 thousand people (in 2019). But the staff professionalism and qualification have increased. JSC Russian Railways has been introduced the continuous education system on the basis of corporate educational institutions for the development of the company's HC, considering the increased requirements for production and labor efficiency. The modern approaches and teaching methods make it possible to effectively manage the staff knowledge, to build human resources capacity. More than 219 thousand people $(18.25 \%$ of the total staff number) received vocational training, retraining and advanced training in 2002, there were already 377.3 thousand people (51\%) in 2019. [1-2, 18-19]

The company takes measures to increase labor productivity by reducing labor costs in the context of improving technologies and technological processes. Labor productivity in transportation activities increased by $3.3 \%$ in 2019 compared to 2018 . The growth rate of labor productivity boosted from $97 \%$ (in 2004) to $115.2 \%$ (in 2019). [2]

Competitive wages of the company staff enhance the prestige of the railway industry occupations and reduce the skilled staff loss. The average staff wage grew evenly from RUB8,325 in 2002 and reached RUB58,504 in 2019. Real wages increased by $1.9 \%$ compared to 2019. At the same time, the staff wages are $23 \%$ higher than the average wage in the country. [1]

Scientific and technological development (STD) of JSC Russian Railways is being carried out in accordance with the Strategy of the company for the period up to 2030 [2]. RUB1,031 million were disbursed to finance the STD measures in 2019, RUB361.2 million were disbursed for the implementation of cost-effective projects (18 thousand people were rewarded). The innovative development program allows the company to cut costs and increase competitive advantage. [1, 18]

The company has developed the Program for the rational use of natural resources, improving environmental safety and preserving natural systems until 2030. According to the Program, JSC Russian Railways has reduced greenhouse gas emissions to $75 \%$ (to 38.5 million tons of $\mathrm{CO}_{2}$ ) by 2020 compared to 1990 . More than $80 \%$ of waste is used by the company as recyclable materials. [19]

Vision Zero was introduced in 2018 to develop the HSE management system at JSC Russian Railways. The Program for the improvement of working conditions and labor protection was developed at JSC Russian Railways until 2030. Working conditions have been improved for 40.6 thousand workspaces, which employ 187 thousand workers. Labor safety expenditures amounted to RUB5,500 billion in 2004, but increased by $23 \%$ and amounted to RUB23,914.6 billion by the year 2019. RUB1.2 billion were spent on traffic safety in 2004 and RUB3.7 billion in 2019. The level of general injuries decreased by $10 \%$ at the end of 2019 compared to 2018 not only thanks to the developed measures, but also to the trained staff. [18]

Focused investments in human capital development of the company and science led to an increase in JSC Russian Railways net profit in the period under review from 2002 (RUB2.8 billion) to 2019 (RUB53.5 billion) [1]. The statistics, programs and development trend of the company indicate a significant rate of development of JSC Russian Railways in 2002-2019. Currently, JSC Russian Railways is able to overcome many problems thanks to modern methods of staff development and creates new opportunities for the company's human capital development. 
The publication was supported by the Russian Foundation for Basic Research, Grant No 19-29-07168

\section{References}

1. JSC «Russian Railways»: Annual report (2002-2020).

2. Russian Railways development strategy until $2030 \mathrm{https}$ //company.rzd.ru.

3. N. M. Baranova, National Interests: Priorities and Security, 15(10), 1802, (2019).

4. V. M. Matyushok, N. M. Baranova, L. V. Sorokin, Springer, 21, (2020).

5. L. S. Mazelis, E. D. Emtseva, E. V. Krasova, A. A. Kras'ko, J. Trends and Management, 4, 97, (2018).

6. E. N. Golovanova, Investment in the human capital of the enterprise, INFRA-M, (2019).

7. D. Kevin Carlson, and Michael J. Kavanagh. Predictive HR Analytics: Mastering the HR Metric, (2018).

8. M. Yu. Dementyev, A. O. Lesnetskaya, Young Science, 36, (2016).

9. N. Ya. Sinitskaya, Scientific review. Economic sciences, 2, 182, (2016).

10. M. Armstrong, and S. Taylor. A Handbook of Human Resource Management Practice, (2018).

11. E. Cahyaningsih, D. I. Sensuse, A. M. Arymurthy, W. C. Wibowo, Procedia Computer Science, 124, 61, (2017).

12. M. Diaz-Fernandez, S. Pasamar-Reyes, R. Valle-Cabrera, BRQ, 20, 63 (2017).

13. N. A. Ershova, J. Management Accounting, 2, 185, (2021).

14. M. Pasban, S. H. Nojedeh, Elsevier, 230, 249 (2016).

15. S. V. Sharokhina, T. A. Shevchenko, O. K. Kokorina, J. Innovation and Investment, 2, 72, (2021).

16. A. A. Titov, Young Scientist, 51(237), 296, (2018).

17. K. A. Myachikova, O. V. Selina, XI Ural Demographic Forum, 77, (2020).

18. JSC «Russian Railways»: Sustainable development management (2002-2020).

19. JSC «Russian Railways»: Environmental Protection (2002-2020).

20. T. Caliari, \& T. Chiarini, Knowledge production and economic development: Empirical evidences. J. Knowl. Econ., (2016).

21. D. A. Ackerberg, \& K. Caves, G. Frazer, Econometrica, 83, 2411 (2015).

22. M. Srholec, Prague Econ. Pap., 25, 53 (2016).

23. J. M. Wooldridge, Introductory econometrics: a modern approach (2015).

24. V. M. Matyushok, S. A. Balashova, I. V. Lazanyuk, Basics of econometric modeling using Eviews, (2015). 